\title{
Mexico's Energy Reform: Inconsistencies after Four Years of Operation
}

\author{
Roberto Gutierrez-R. \\ $\mathrm{PhD}$ in Social Economics \\ Chief of the Department of Economics \\ Autonomous Metropolitan University \\ Campus Iztapalapa, Mexico City
}

\begin{abstract}
The 2013-2014 energy reform represents a breakthrough to the long-lasting energy state-monopolies inaugurated in 1938 with the hydrocarbon industry. The new two-tier structure involves the coexistence of one large but diminishing public enterprise in both hydrocarbon and power industries and many international companies acting alone or in association with small-sized domestic firms. With such a structure, the expectations are that the Mexican energy sector becomes a new vehicle for economic development, mainly based on hydrocarbons exploration, exploitation and transformation, and on cheap electricity prices. After nine auction exercises in the hydrocarbon industry and three in that of power, carried out between 2015 and 2018, which allow large and midsized international oil companies to explore and exploit onshore, shallows and deep-water hydrocarbon recourses, and international power companies to take large amounts of power into the grid, foreign investment does not start to flow as the reform expected. The only changes the sector has undergone so far are in the areas of fuels imports and retail sales. Though the international market remains a buyers' one, and prices recuperate slowly, companies should feel encouraged to initiate the projects they were committed to, so reinforcing Mexico's oil, gas and derivatives production, rather than making profits by importing gas and fuels. To avoid private companies determine national energy policies and have a disproportionate influence on macroeconomic decisions, regulations ought to be clear and the state be committed to enforce them.
\end{abstract}

Keywords: Hydrocarbons, energy reform, public economics, economic development, energy policy.

JEL Classification: L71, H30, O10.

\section{Introduction}

In a historic process which considers the configuration of the Mexican energy sector, its nationalization in 1938, its macroeconomic impacts, and its re-privatization by means of the 2013-2014 energy reform, this paper casts its sight on the promises that such a reform has not been able to fulfill four years after its enactment. The hypothesis is that local production of crude oil and gas could satisfy the mid and long term needs of the country's foreign exchange and final products domestic demand only if the authorities stand to the energy objectives established when the energy reform was discussed. The more the state separates itself from its original energy policy design, the most the country will increase its dependency on foreign gas and refined products, and the energy trade balance and public finances will deteriorate. In the process of discussion, also the needs to enhance energy production capacity at both primary and secondary level and to diversify energy sources are considered. To develop these ideas the paper proceeds as follows. In the first section, a brief demarcation of Mexico's energy sector is presented. In the second, the levels of primary energy production and reserves are analyzed. In the third, as a background the nationalization process of the oil industry and other considerations are presented. In the fourth, the relationship between energy and macroeconomics is considered. In the fifth, the main characteristics of the energy reform are analyzed. In the sixth, the real outcomes of the reform after four years in place are considered. In the seventh, the issue of a serious energy policy is undertaken. Then the conclusions are addressed.

\section{A brief demarcation of Mexico's energy sector}

Mexico's energy sector is integrated by two large industries: hydrocarbon and electricity, and a small branch gaining participation on energy production: alternative sources. A few decades after coming into being, the two industries turned into state monopolies, declared so during President Cardenas administration (1934-1939). 
In 1937, he promulgated the liquidation of private capital in the electricity industry, and in 1938 the creation of one vertically integrated state enterprise in the hydrocarbon industry, Petroleos Mexicanos (PEMEX) was decided. The former led to the formation of two vertically integrated state power enterprises, Comision Federal de Electricidad (CFE), and Luz y Fuerza del Centro (LFC), consolidating a legal state duopoly in 1960, right at the beginning of President Adolfo Lopez Mateos administration (1960-1965).

In 2009 LFC was liquidated and CFE became a real monopoly, but not for long. During 2014-2015 both oil and electricity monopolies came to an end by the energy reform promulgated by President Peña Nieto (2013-2018), first constitutionally (2013) and then by issuing or transforming 21 energy sector secondary laws and 25 regulations (2014). As a result, in terms of property the oil industry is now two-tier. The state-owned tier, i.e. PEMEX, will accommodate itself slowly to the new market structure, and its share in the industry will progressively descend. The private sector tier is bound to grow rapidly and in a few years, could dominate the industry. It is composed by three kinds of companies: Foreign, local, and all possible associations between them. Both in consortia or alone, the large foreign firms will be the operators of the projects and the domestic ones will act as the followers because of lack of expertise, financial resources and technological capabilities.

A similar two-tier division is observed in the power industry, tough the structure started to be configured by a secondary law enforcement during the mid 1990s, when private companies were allowed to participate in the industry by adding generation capacities to the system, the only restriction being that they could not sell energy directly to final consumers, but to CFE. This monopolistic system gave also private companies the opportunity to participate in the industry by constructing gas pipelines and bringing natural gas into the combined-cycle power generation plants they had also built, as the goal was to reduce the participation of coal, heat-oil and diesel plants in national electricity generation. Thanks to the energy reform, private companies finally can participate all along the power supply-chain, with constitutional reserves on the instances of public service transmission and distribution, and leaving to the state the duties of planning and dispatch. This means that nowadays they can generate and have their own electricity into the grid along with CFE, and at the end of the supply-chain can also sell electricity to large users (mainly the industrial sector).

As for alternative sources is concerned, they now can grow independently from CFE's demand and are increasing its share in final consumption, particularly by means of wind plants, which recently have been growing faster than other sources. The same starts to happen with biogas and solar photovoltaic plants, and is about to happen with thermal plants, where the investment effort is higher. Due to Mexico's hydrological limitations, mostly in the northern part of the country, hydroelectricity seems to be reaching its limits; biomass is bound to decrease due to forest resources arguments, and nuclear energy possibilities can only be a long-term option as the process depends on heavy investment and for security reason it remains constitutionally reserved to the state.

\section{Primary energy production and reserves}

In 2014, Mexico's effective primary energy production amounted to 8,854 petajoules, $92.3 \%$ of which came from fossil fuels: oil, 63.4\%; natural gas, 23.6\%; condensed fuels, $1.9 \%$, and coal, $3.4 \%$. The remaining $7.7 \%$ came from alternative sources: nuclear energy, 1.1\%; hydro energy, 1.6\%; geothermal, solar photovoltaic and win energy, $0.9 \%$; biomass, mainly rewood and biogas, $4.1 \%$; and others, $0.3 \%$ (see figure 1 ). These sources are on its way to become important due to three reasons: the environmental deterioration of producing regions, large cities, lakes and groundwater; international commitments, in which Mexico has played an active role, such as the COP 21; and a rapid depletion between 2004 and 2016 of proven hydrocarbon reserves (-47\%) and hydrocarbon production (-35\%). 
Figure 1. Mexico's effective primary energy production composition (\%)

On the bases of 2014 production of 8,854 Petajules*

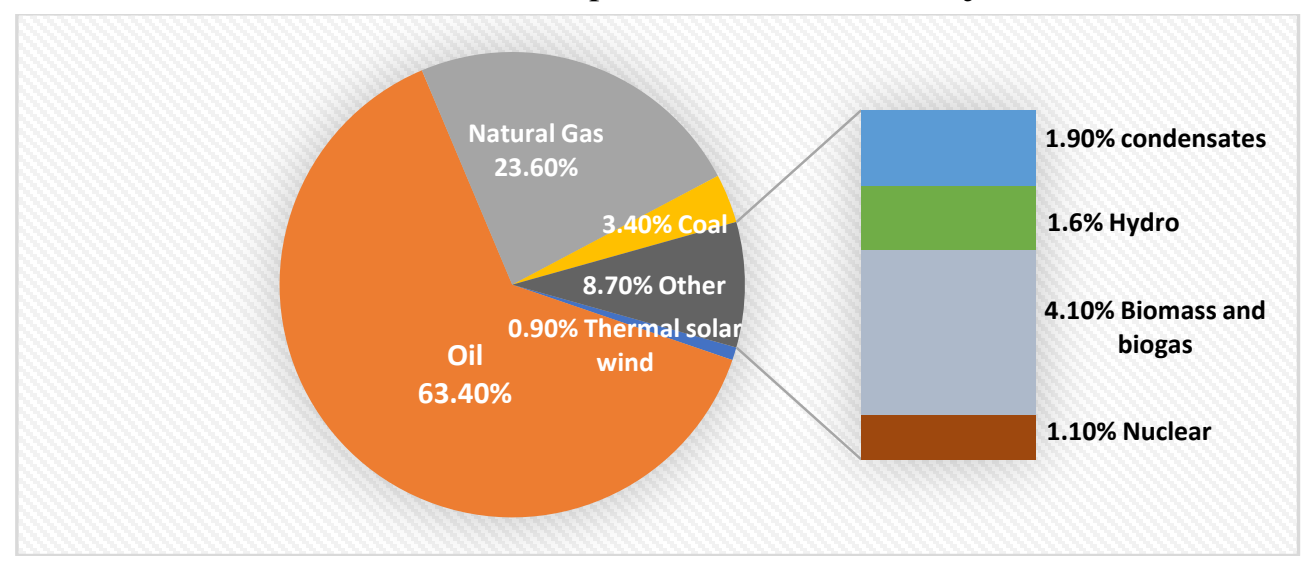

$*$ One petajoule $=238,845.9$ gigacalories

Source: SENER (2018)

In 2015 total effective production dropped by $-6.7 \%$ in relation to that of 2014 and by $-16.7 \%$ compared to that of 2005 , when it amounted to 10,625 petajoules. The reason for this was particularly the declination of the megafield Cantarell, located in the shallows of Mexico's southeast region, which production came down from 2.4 million barrels per day (MMBPD) at the end of 2004, representing 63\% of the country's national production, to 185 thousand barrels per day (TBPD) in June 2017, representing only 9.2\% of national production. Through the production of another big field in the same region, Ku-Maloob-Zaap, attenuated the Cantarell's drop effect and corroborated how well-endowed is the Gulf of Mexico in terms of hydrocarbons, overall oil production exhibited an annual rate of declination between 2004 and 20017 of -4.2\% (SENER, 2017; SENER, 2016; PEMEX, 2017).

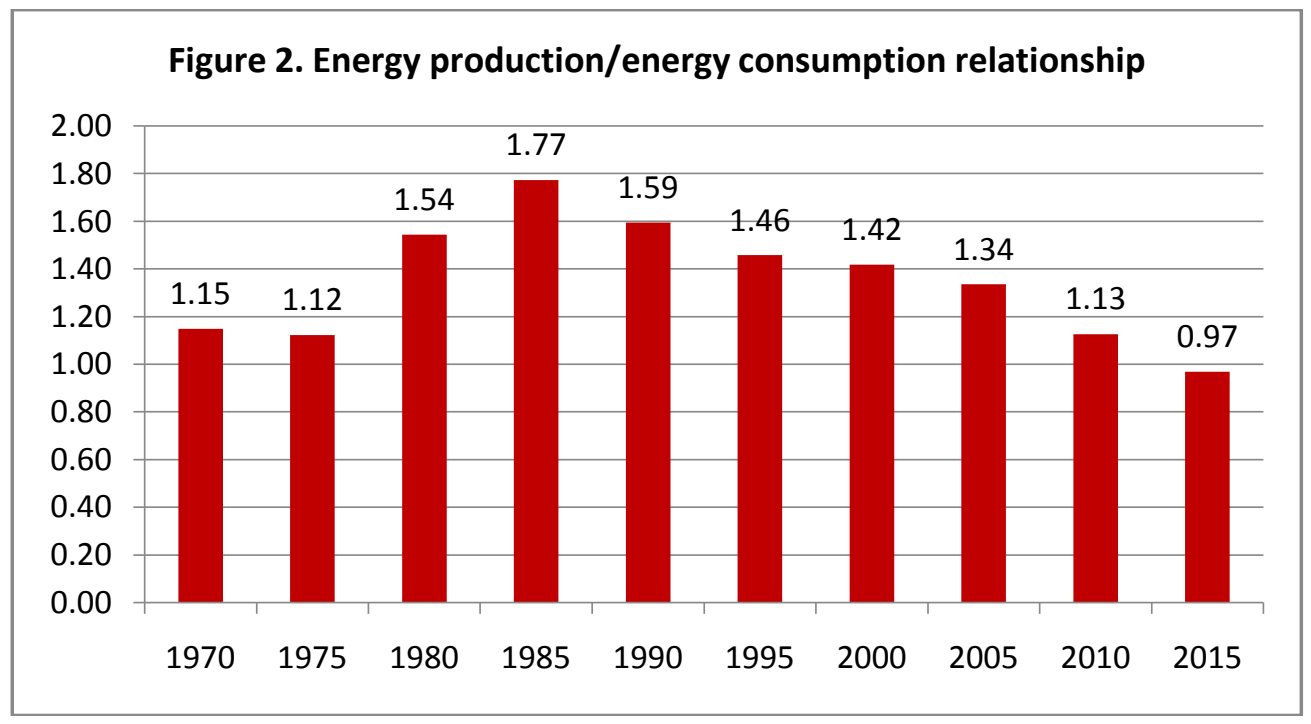

Source: SENER (2018)

The effect of Cantarell's depletion on the production of natural gas did not show up immediately, as associated gas production kept growing and that of dry gas increased steadily thanks to the intensification of dry gas production in Mexico's Northeast region, particularly in the province of Burgos. The peak of production was reached at the end of 2008, 7,359 million cubic feet per day (MMCFD), quite enough to cover national demand. From that point on it started to fall, coming to 5,288 MMCFD at the middle of 2017, an annual average drop of $4 \%$. Due to this fact, and to the transformation of national industrial activities, particularly that of power generation, which was reoriented to consume natural gas instead of liquid fuels, consumption of natural gas kept growing as well as imports. At the middle of 2017 the latter represented about $40 \%$ of national consumption. Such a figure is higher in the cases of gasoline and diesel (Mexico holds only six refineries and they operate between $40 \%$ and $50 \%$ installed capacities). Besides, the country depends on the imports of multiple petrochemical products. 
Crude oil is, on the other hand, the only fuel that Mexico exports abundantly: 1.2 MMBPD in 2018 (SENER, 2017; SENER, 2016; PEMEX, 2018). In view of this, since 2015 Mexico's consumption of energy in terms of petajoules lags behind its production, as figure 2 shows.

If petrochemical products are added to the previous relation, the exports of energy in terms of foreign currency are lower than those of imports, as shown in figure 3. Both exports and imports are mostly carried out with the U.S., and the intra-trade industry deficit of Mexico with that country in terms of hydrocarbons and petrochemicals is considerable.

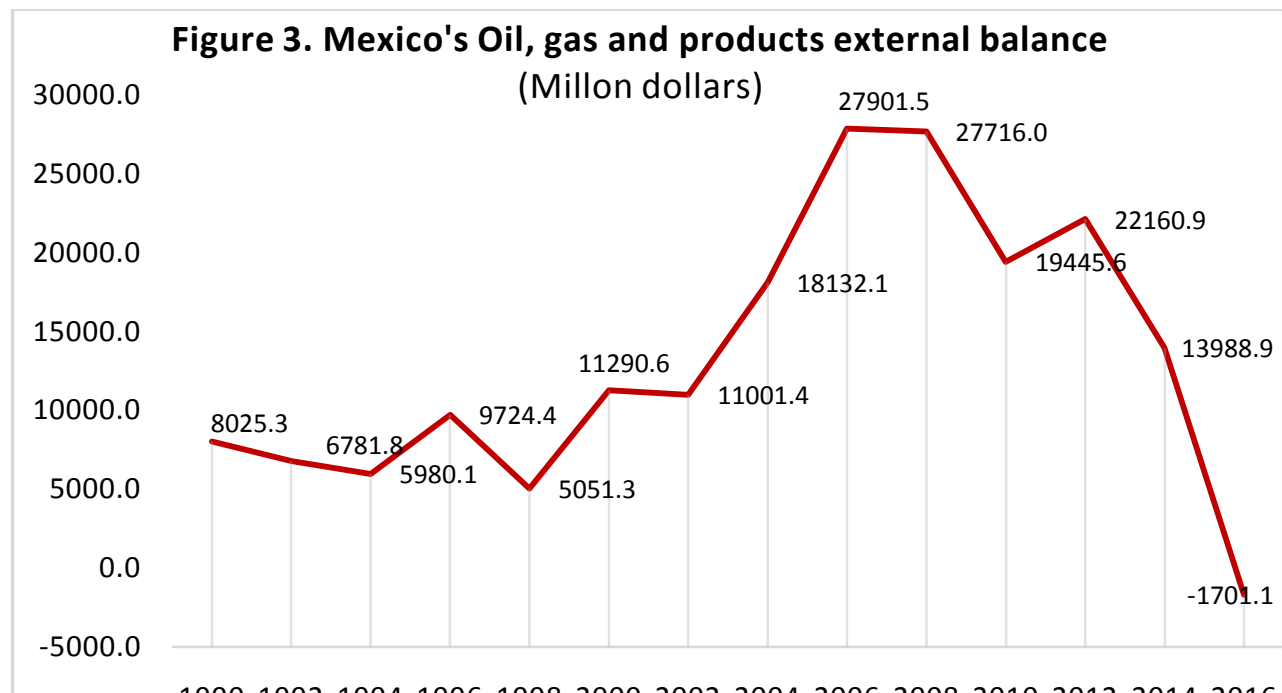

19901992199419961998200020022004200620082010201220142016

Source: PEMEX (2017)

Proven hydrocarbon reserves have been falling at a faster speed than production during the recent years: In 2005, they amounted to 17.5 billion barrels of oil equivalent (BBOE); by early 2017 they have fallen to $8.56 \mathrm{BBOE}$, a $5.9 \%$ annual average rate of reduction. Therefore, the expected life of proven hydrocarbon reserves came down from 10.3 years in 2005 to 8 years in 2017 and 7.5 in 2018, and the average replacement rate was close to 0.75 all along the period, but in 2016 came down to about 0.10 due to the low rate of investment in productive and development wells (SENER, 2018; SENER, 2016; PEMEX, 2016; PEMEX, 2007).

Mexico's deep-water hydrocarbon resources are estimated close to 26.5 BBOE (Senado de la Republica, Diario de Debates, 2013), and the U.S. Energy Information Administration estimates the county's shale oil reserves to be the eighth largest in the world, and those of shale gas to be the sixth (USEIA, 2017). Different analysis show also that Mexican geological formations can be considered extensions of commercially productive U.S. formations; that is the case of the Eagle Ford formation in Texas. Otherwise, Mexican formations are surely correlated to commercially productive U.S. formations. The same association stands for the resources in deep-water of the Gulf of Mexico. Despite these facts, exploration and production activities are intense in shale oil, shale gas and deepwater on the U.S. side, and still insignificant on the Mexican side.

In the power industry, effective generation capacity for commercial uses in 2015 was 54,825.4 megawatts (MW), from the following sources: conventional thermoelectric plants (liquid hydrocarbons and natural gas), 62.6\%; hydroelectric plants, 21.9\%; coal driven plants, 9.8\%; nuclear power plants, 2.8\%; and renewable sources (geothermal and wind power plants), 2.7\%. Biomass energy is not included, as it has not a commercial character, and solar photovoltaic energy as well as certain kinds of bioenergy is not mentioned as they have a rather low participation on commercial energy. Surprisingly, this structure has not improved vis-à-vis that prevailing 30 years ago, when the first steps to substitute traditional energy sources by renewable ones were undertaken. In 1986, conventional thermal power stations were the source of $62.6 \%$, and hydroelectric plants of $30.7 \%$ (Wionczek, Guzman and Gutierrez-R., 1986). After three decades, hydroelectric plants lost nine percentage points of participation; coal plants, which are by far the most environmentally aggressive, gained 5.4 percentage points; geothermal power plants remained almost unchanged; and a $2.8 \%$ increase was observed in nuclear power due to the incorporation of the Laguna Verde plant, on the eastern coast of Mexico. Wind generators established themselves with almost 1 per-cent. 
The bulk of the structural change has come about due to: a) lowering the participation of hydroelectric plants; b) increasing the number of natural gas thermoelectric plants, and c) accelerating the substitution of conventional liquid fuels thermoelectric plants. Nowadays, combined-cycle plants and turbo-gas plants, both powered by natural gas, represent together $41.3 \%$ of the effective power generation capacity, whereas the participation of plants powered by liquid fuels fall to 20.8\% (Gutierrez-R., 1990; SENER, 2016; SENER, 2018). Two points should be underlined. Besides combined-cycle and turbo-gas plants, the wind powered ones have had the highest growth in the industry in the last decade. Their prospects for development have increased due to the strong winds that blow across some Mexican states, among them Oaxaca, Tamaulipas, Coahuila, Baja California and Nuevo Leon. This has attracted the interest of several Spanish and U.S. firms already established in Mexico. Additionally, of the existing 54,825.4 MW effective commercial generation capacity, about two thirds belong to the CFE, with a great deal of idle capacity, and the remaining $33.3 \%$ to private companies. Out of this, $11 \%$ is sold to CFE for distribution along the National Electrical System, and the remaining 22\% is distributed in different ways including producers' self-consumption (7\%) and exports (2.2\%) (SENER, 2016; SENER, 2018).

\section{The historical background}

Mexico's economic development has been closely associated to the development of the energy sector. At the beginning of the $20^{\text {th }}$ century, income earned from energy exports satisfied the country's development needs. Mexico was then a primary commodity exporting country and had been so since colonial times because of its tremendous mineral resource endowments. However, during the 1910s, oil began to emerge as a main export and by the early 1920s Mexico became the world's largest oil exporter displacing mining as the nation's main exporting industry. However, there was the popular feeling that the benefits of this exploitation would be reaped by several international oil companies to which the Mexican government had granted almost limitless exploitation rights in the form of concessions.

The high growth rate of domestic oil consumption, together with the rapid expansion of other major oil regional producers, reduced soon Mexico's contribution to world crude oil exports. This trend was accentuated after 1938 because of Mexico's temporary isolation due to the nationalization of the oil industry, and also due to the explicit decision of the government to utilize its controlled oil production mainly to stimulate domestic industrialization.

The hydrocarbon industry nationalization resulted from a deteriorating relationship between the international oil companies and the Mexican government. The conflict started between the Union of Oil Workers of the Mexican Republic (STPRM), formed in August 1935 with the sympathy of President Cárdenas, and the oil companies, whose first action consisted of writing a collective labor contract for the entire oil industry. The proposed agreement included provisions for a working week of 40 hours and payment of full wages in case of illness. The oil companies refused to accept these provisions. In May 1937, the workers decided to go out on a preventive strike. In response, the oil companies filed a lawsuit to the General Board of Conciliation and Arbitration (JGCA). The strike expanded during the first nine days of June 1937. In July, the JGCA convened a Commission of experts to investigate the financial situation of the oil companies, concluding that their financial gains allowed them to meet the main demands of the workers.

In December 1937, with no response from the JGCA, another work stoppage occurred. Shortly thereafter, the Court ruled in favor of the Union. An award was made to the Union which required the companies to accede to the contract demands of the Union and the payment of 26 million pesos in wages. In January 1938, the latter filed a request to be protected from the law before the Supreme Court. As a result, the members of the Union declared themselves in rebellion. The ruling of the judicial authority was unveiled at the beginning of March 1938, noting that the time limit the companies had to pay the 26 million pesos was a week.

President Cardenas held meetings with the owners and directors of the companies during that period. But when at the last meeting he asked for the payment of the 26 million pesos as a guarantee to lift the strike, he received an improper reply by one of the owners, who even questioned his authority. This motivated him to end the talks. At the last meeting, on the morning of March 18 the companies declared they would be willing to make the payment, but the President had already taken the decision to expropriate the industry. This was announced that evening on the bases of a pre-existing Law of Expropriation (November 23, 1936) and the article 27 of the Constitution of 1917, which had not yet been implemented.

In response, several foreign governments took diplomatic or trade actions: The United Kingdom broke diplomatic relations with Mexico; the U.S. and the Netherlands announced a trade embargo against the country, and withdrew all their technical staffs from productive areas. 
Further, the U.S. Treasury stopped purchasing Mexico's silver for which it was the exclusive customer. The oil purchased by U.S. companies was replaced by imports from other nations. The trade embargoes resulted in exhaustion of almost all the gasoline reserves in Mexico. This resulted primarily because Mexican workers did not know how to synthesize tetraethyl lead, a compound used to graduate the octane rating of the fuel. Through experimentation this situation was eventually resolved in two stages. The first consisted of bringing together the best oil chemists in the country; but when the investigation was well advanced, an accident resulted in the death of many of them.

The second consisted of gathering outstanding chemistry students of Mexico's Autonomous National University (UNAM) and the National Polytechnic Institute (IPN), which President Cardenas had founded. After many efforts, they finally managed to synthesize the compound (Gutierrez-R., 2017: 54).

The conflict of 1938 occurred in a period of decline of oil production since, except for the discovery of the Poza Rica area (1933), the international oil companies said that they had evidence that Mexico's oil resources were running out and the extraction in mature wells was very expensive. Therefore, instead of investing in Mexico they moved to Venezuela, with its lower extraction costs due to new discoveries of oil in the Lake Maracaibo. At the same time, they argued that from President Madero's administration (1911-1913) on, their profits had declined due to the increase of taxes and royalties. Also, they complained that article 27 of the Constitution placed them in a fragile situation that was increased by the rigidity of the subsequent governments, ranging from Obregon (19201924) to Cardenas (1934-1940).

In practice, oil nationalization did not turn into a financial burden for the country as multilateral solidarity came about once Mexico defined its position in favor of the Allied countries during the Second World War, then increasing its exports of natural resources, including oil. At the same time, Mexico changed to a new model of growth, that of import substituting industrialization, which lasted until the early 1980s. During the process, the share of raw materials on total exports fell considerably, and the percentage of manufactured exports increased gradually.

\section{Energy and macroeconomics}

Mexico's Gross Domestic Product (GDP) rate of growth from 1940 to 1980 was one of the highest of the developing countries thanks in part to the fact that energy supply grew faster than the aggregate product. As during the first stages of industrialization, the income elasticity of energy demand is considerably higher than unity, it is not surprising that since the early 1950s up to the mid 1980s oil shifted from being a source of foreign currency to support the industrialization and urbanization processes. Further, installed capacity in the power industry grew at an average annual rate close to $10 \%$, which means that it doubled every seven years.

Between the mid 1970s and mid 1980s, oil became fundamental to the Mexican economy. The development strategy of that period benefited from the rapidly rising oil price; then the rebirth of the Mexican hydrocarbon industry came about. New resources discovered in the southern part of the country, particularly the Cantarell field, in the shallows of the state of Campeche, supported growth. National crude oil production increased from 717,000 barrels per day (BD) in 1975 to 2.630 million barrels per day (MBD) in 1985: an almost four-fold increase in 10 years. By the same token, total supply of primary energy increased at an annual average rate of more than $12 \%$. The energy sector, which had accounted for $3.2 \%$ of the GDP up to 1970, increased its share to $5.7 \%$ by 1983 and reached 7\% in 2012 (2002-2012 was a renewed period of increasing oil prices) (INEGI, 2014; PEMEX, 2016).

Not only during the late 1970s and early 1980s but up to 2013, the energy sector was the one contributing most in absolute terms to the creation of jobs: in direct terms, the number of employees of PEMEX rose from 72,500 in 1970 to 155,000 in 2013, and that of the power duopoly CFE-CLFC, went up from 38,000 in 1970 to almost 90,000 in 2013, even though by the latter year CLFC had been liquidated (PEMEX, 2014; CFE, 2015; NAFIN, 1996; LFC, 2008). The rate of job creation in the energy sector helped bolster the country's labor market because the economically active population was growing at an average annual rate over 3.5\% during the 1970s and 1980s (INEGI, 2014b).

Furthermore, taxes on hydrocarbon exports, which were virtually nonexistent in the 1970s, became the most important source of income for the state along with the duties on domestic sales paid by PEMEX and other energy entities: They accounted for up to $50 \%$ of the federal government's budgetary income in some years. Although the name and nature of federal taxation has changed over the years, the share provided by oil remained high up to 2013 (SHCP, 2018). 
Also, the energy sector benefited most from the annual allocation of the federal budget during PEMEX expansion in the late 1970s and early 1980s. At that time, the share of total public expenditure held by the energy sector amounted to one third. Energy participation on the GDP declined to almost 5\% by 2016, after oil prices fell (INEGI, 2014; PEMEX, 2016). The economically active population rate of growth came down to $1.9 \%$ by $2004-$ 2016 (STPS, 2018). PEMEX rewarded the state not only with growing levels of resources, royalties, and a highincome capacity but also with the image of great international solvency. Thus, PEMEX became the public enterprise with the greatest external financing capacity.

This was used to considerable advantage by the state first to expand productive activities, and after the economic crises of 1982-83 to service Mexico's national debt as well as to finance ongoing government expenditures. However, this growth did not keep pace with public or PEMEX investments required to promote long-term economic growth. As a result, the rate of reserves replacement became less than 1.00 year after year, and the useful life of hydrocarbon reserves declined from over 50 years during the 1980s to only 7.5 years by 2017 (SENER, 2017). Even with those problems, the energy sector contributed to the industrialization of the country during a long period of time and helped accelerate growth of GDP by granting subsidies to industrial firms. It also benefited local consumers with controlled fuel prices, fixed by the Ministry of Finance and Public Credit (SHCP).

During the late 1970s and early 1980s Mexico became less concerned about its economic vulnerability and adopted a short-term oriented policy. This policy was based on public sector expenditures to maintain high rates of economic growth thanks to the fast production of energy resources and currency generation, but lacked a longterm vision regarding the capabilities of other economic sectors and branches, the foreign debt burden, the national currency pressures, and the consumer price index stability.

Such a policy was in part a continuation and also the abrupt rupture with the import substituting industrialization model. On the one hand, the allocation of foreign exchange was scare for almost all sectors except that of hydrocarbons, thus limiting their capacity to export. On the other, it provoked a fast process of import liberalization as national production lagged far behind demand. In spite of the increasing current account deficit, the national currency kept fixed to the dollar. It was Mexico's version of the 'Dutch disease'.

As of 1981-82, the coefficient of economic openness, (that is, the percentage of GDP accounted for by exports plus imports), was just over $20 \%$, and the share of oil in total exports was over $70 \%$, just as international oil prices peaked and then started declining. To make matters worse, international interest rates sharply increased. At that time, Mexico found itself with insufficient resources to service the second largest developing countries foreign debt. The dependence on oil resources was crucial for foreign currency purposes at least up to the mid 1990s, when a large devaluation of the peso came about and Mexico's regime of a fixed rate of exchange came to an end. Oil reserves acted as a guarantee for a rescue package of almost USD 49 billion organized by the U.S. government and the International Monetary Fund (IMF).

The adoption of the export-led growth model was reinforced by Mexico's accession first to the General Agreement on Trade and Tariffs (GATT) in 1986, and then to the North American Free Trade Agreement (NAFTA) in 1994. Also, in the latter year the country became the $25^{\text {th }}$ member of the Organization for Economic Co-operation and Development (OECD), subscribing that organization's commitment to democracy, free trade and sustainable economic growth and employment generation. Those actions fostered a structural change in the Mexican economy shifting definitely from production for domestic consumption to exports. The openness coefficient increased in 2000 to over 55\% and went to $63 \%$ in 2016. Also, a structural change came about in exports, with $85 \%$ accounted for by manufacturing from the late 1990s onwards, and a reduction to less than $10 \%$ by oil. Although with the recovery of international oil prices between 2010 and 2014, the oil share increased to $17 \%$, these levels were not sustainable, as shown in the following section.

\section{$V$. The 2013-2014 energy reform}

Mr. Enrique Peña Nieto, who brought back the presidency of the Republic to the Institutional Revolutionary Party (PRI) after it had been during two sexenia in hands of the National Action Party (PAN), did not want to wait for the slow pace of productive activities the 2008 no-constitutional energy reform offered, and considered that through political arrangements not only a constitutional transformation for the energy sector could be negotiated, but also a whole package of 11 structural reforms, including telecommunications, public revenues, finance, education, justice, and fair competition. 
Thanks to the support of the PAN, PRI's largest rival in the Congress, and other right-win and center smaller parties, negotiations toward such structural reforms proved fruitful. Left-wing parties were never convinced that the energy reform was necessary to support the development of the hydrocarbon and electricity industries - they rather believe that PEMEX and CFE can accomplish that by themselves if they were properly administered. Numerous surveys on political beliefs and national sentiment on the oil industry were carried out in the country by qualified institutions during 2007-2014 and showed that at least 66\% of Mexicans did not trust international oil companies.

Respondents bear in mind the split between oil companies and the government in 1938. They also seem to recall the paragraph six of the article 27 of the political constitution valid prior December 20, 2013:

"In the case of oil and solid, liquid or gaseous hydrogen carbides or radioactive minerals, no concessions or contracts shall be granted, nor the existing ones shall be valid, and the Nation shall carry out the exploitation of such products in the terms established by the respective Regulatory Law. It is the exclusive responsibility of the Nation to generate, conduct, transform, distribute and supply electric energy for the purpose of providing public service. In this matter concessions will not be granted to individuals and the Nation will take advantage of the goods and natural resources that are required for these purposes."

The energy reform was made possible because the government had the capacity both to negotiate it properly in the Congress and temporarily convince people that such a reform will allow the country to have enormous benefits in the short-run. The main promises were that:

a) The energy sector will be receiving up to 50 billion dollars foreign investment per year from 2014 on.

b) Mexico's GDP growth would overcome by 1.5-2.0\% its 1990-2012 trend, which had been 2.2\%. This coupled with the outcomes of the other 10 structural reforms put in place during the first 14 months of Mr. Peña Nieto's administration, will allow Mexico's rate of growth to reach $5.5 \%$ by 2015 .

c) Such a high rate of growth will generate, only in the energy sector, 500 thousand jobs between 2014 and 2018 (100 thousand annual average).

d) By 2018, oil production would reach $3 \mathrm{MBD}$, and that of gas would be 8 BCFD.

e) Energy prices would fall, mainly those of gas, power and transportation fuels oriented both to domestic and industrial consumption, as the country should keep control of its price level and recuperate the competitiveness it was about to lose because of the high level of the energy prices.

f) Oil, gas and power upstream activities such as refining capacity, primary petrochemicals production, pipeline transportation, fuels storage, gasoline service stations and the like would receive a big push.

g) In the areas of technology and administrative and operational efficiency, PEMEX would stop being a burden for the country and would advance as Statoil of Norway had done since the 1970s, and Petrobras (Brazil) and Ecopetrol (Colombia) had done from the 1990 on without losing their state participation.

h) A greater integration would be achieved in the value chains of the hydrocarbon and electric industries, then allowing for Mexico's industrial development and technological spillovers.

i) Due to the rapid development that the hydrocarbon industry would undergo during the following years, the curricula of the Mexican universities would have to be modified to prepare the professionals that such an industry would demand.

j) Both the public finances and the external accounts would be strengthened by virtue of a stronger energy sector.

k) The opportunity that the energy sector was giving to Mexico would be accomplished from a sustainable development point of view involving both the energy sector and the whole economy.

1) The proper use of oil income, coupled with the creation of a Mexican Oil Fund administered by the central bank, would guarantee a process of inclusive development for Mexico, focusing on the eradication of the extreme poverty, the reinforcing of education, the delivery of justice, The improvement of Mexican people's technical capacities, and the creation of infrastructure (Senado de la Republica, Diario de Debates, 2013).

During the Round Zero, which initiated the privatization process of the oil industry, PEMEX received from the Ministry of Energy (SENER) assignments of oil fields both productive or with different degrees of known reserves, and was given the responsibility either to develop them or to keep them producing. The reform allows PEMEX to enhance production and develop the fields either alone or in association with private national or international enterprises; but, as a state company in a competitive market, it is not allowed to hold monopoly power in any part of the supply-chain. 
The second adjustment to the oil industry, known as Round One, consisted of opening the areas of exploration and exploitation of hydrocarbons to a great number of national and international private companies. This round was accomplished in December 2016, after four auctions were carried out during one and a half years in relation to hydrocarbon fields in mainland and the Gulf of Mexico's shallows and deep water. The process continued with Round Two up to January 2018 with four more auctions, and with Round Three, auction 1, in October 2018. It was expected that it went on with Rounds Three and Four during 2018-2019, according to a statement of SENER (2015), though the administration taking office on December 1, 2018 may change priorities.

Particularly important in this regard is that PEMEX leaves completely the gas business to private companies and starting January 1, 2017 shares with them the imports of refined products and the first-hand distribution of gasoline and diesel. So, PEMEX becomes only one of a variety of franchises operating service stations in the country. Besides, the concept of a state petrochemical products industry, which used to be constitutionally associated to the oil industry, disappears and such products can be produced and distributed by any private company, including PEMEX. Even more, to facilitate the transportation of gas and refined products, PEMEX is obligated to share its pipeline network and storage capacity with private enterprises authorized by the Energy Regulatory Commission (CRE).

A similar two-tier division is observed in the power industry. The restructuring of it, which started during the mid 1990s, allowed private firms participation in the industry through addition of generation capacity to the system. The only restriction was that they could not sell energy directly to final consumers but only to CFE. This structure gave private firms the opportunity to participate in the industry by constructing gas pipelines and bringing natural gas into power generating combined-cycle plants. The energy reform did not extend to public power transmission and distribution, and planning and control remained in state hands. This means that private firms can produce and transmit electricity into the grid along with CFE, and at the end of the supply-chain can also sell electricity to large users, mainly from the industrial sector. In the middle of the process a state body, the National Center for Energy Control (CENACE), independent from CFE, transmits electricity and administers and dispatches it to final distributors. Planning is performed by SENER with regulatory oversight by the CRE. To mitigate CFE's monopoly power in transmission and distribution, except for the segment of public service, the resulting structure provides open-access and greater consumer choice.

The restructured industry allows for the independent growth of the share of electricity sourced by non-fossil fuels. Due to the image that underpins renewable energy and Mexico's endowment of wind, biogas, geothermal and solar photovoltaic, these sources have been growing faster than others during recent years. Mexico's hydrological limitations, mostly in the northern part of the country, imply that hydroelectricity should be reaching its limits; biomass is bound to decrease due to forest resource conservation arguments; and nuclear energy can only be seen as a long-term option as its development depends on heavy investment and for security reasons such facilities remain constitutionally a state monopoly.

\section{2015-2018 out comes}

Right after the 2013-2014 energy reform was promulgated, Mexico's energy sector situation worsened, facing ironically a series of problems not seen all along its life span. Such problems were motivated by the accumulation of erroneous energy policy decisions which surfaced due to the reversal of a long-lasting international oil market boom, not foreseen by the Mexican authorities. The facts are as follows:

- The Mexican oil-mix export price deteriorated from an average 98.79 dollars per barrel (D/B) in June 2014 to $23.91 \mathrm{D} / \mathrm{B}$ in January 2016, a $76 \%$ contraction in less than two years. During the three following years it recuperated 60\%: By November 2018 it reached 70 D/B (PEMEX, 2018). This rather slow reversing process had not precedents since the 1980s oil crisis. Both 1980s and 2010s crises can perfectly be explained as a result of the hydrocarbons oversupply generated after roughly a decade of oil and gas price recuperation. This led, on the one hand, to an increase in the production of some non-OPEC member countries during the 1980s and 1990s and, on the other, to the U.S. shale revolution from 2005 on.

- The situation was aggravated by a reduction in the Mexican production of both oil and gas. The former came down from an average 2.5 million BD in 2013 to 1.89 million BD in 2018, and the later from 6,370 MM3FD in 2013 to 4,845 MM3FD in 2018 (PEMEX, 2018).

- All that in turn implied a reduction of crude oil export revenues for the Mexican economy over 75 billion dollars between 2014-2018 in case the 2013 price had kept constant, as erroneously the government expected. 
The underlying annual average impact of -18.75 billion dollars meant a $-1.8 \%$ reduction in terms of the GDP. Consequently, the share for oil exports on total merchandise exports shrank from to $12.8 \%$ in 2013 to $7.6 \%$ in 2018 (PEMEX, 2018).

- Though a big effort was made to keep constant the volume of oil exports during the period (1.19 MBD in 2013 and 1.2 MBD in 2018), the amount of crude oil sent to the refining process had to be reduced. As a consequence, Mexico's six refineries idle capacity grew from $40 \%$ in 2013 to about $66 \%$ in 2018, and imports of gasoline and diesel jumped from 466 thousand BD (39.5\% out from 2013 national consumption) to 826 thousand BD (77\% out from 2018 national consumption) (PEMEX, 2018).

- The share of oil taxes on the federal government budgetary revenues came down from $35 \%$ in 2013 to $18.8 \%$ in 2018, generating pressures on other sources of federal income, particularly non-oil taxes associated to final consumption (SHCP, 2017).

- Also, the federal government decided to reduce the energy sector's participation in the budget from $24.7 \%$ in 2013 to $20.4 \%$ in 2018, affecting particularly PEMEX's, which came down from $15 \%$ in the first year to $10.3 \%$ in the second (SHCP, 2018).

- Obviously, the government expected that foreign oil companies will bridge the gap with fresh investment in the hydrocarbon industry starting 2014. This did not happen, as only in 2015 and 2017 such resources increased slightly in relation to its previous year. Besides, and unexpectedly, the amount received by this industry during the period was less than half that fetch by the power industry, so that out of the 7,773.3 million dollars received by the sector, $31 \%$ was fetch by the hydrocarbon industry and the remaining $69 \%$ by the power industry, as shown in table 1 . Besides, the joint amount represents less than $5 \%$ that cached by the hole economy during 2014-2018 (CNIE, 2018).

\begin{tabular}{|c|c|c|c|c|c|c|}
\hline \multicolumn{7}{|c|}{ Table 1} \\
\hline \multicolumn{7}{|c|}{ FOREIGN INVESTMENT IN MEXICO'S ENERGY SECTOR, 2014-2018 } \\
\hline & & \multicolumn{2}{|c|}{ Million dollars } & & & \\
\hline & 2014 & 2015 & 2016 & 2017 & 2018 j-j & Acummul. \\
\hline Hydrocarbons extraction & 260.1 & 796.3 & 403.9 & 590.8 & 373.1 & $2,424.2$ \\
\hline Power industry & 544.1 & 685.2 & $1,138.2$ & $1,498.1$ & $1,443.5$ & $5,309.1$ \\
\hline TOTAL & 804.2 & $1,481.5$ & $1,542.1$ & $2,088.9$ & $1,816.6$ & $7,773.3$ \\
\hline
\end{tabular}

- Lack of investment in the hydrocarbon industry has had serious effects on the useful life of hydrocarbon reserves, as the relation proven reserves/current production declined from over 50 years during the 1980s (certainly overvalued) to 9.3 years in 2007 and only 7.5 years in 2018 (Gutierrez-R., 2008; SENER, 2018).

\section{The need for a real energy policy}

A preliminary assessment of the first four years of operation of the 2013-2014 energy reform leads to different considerations. First, the goals in terms of increasing oil production have been slowed down partially because of the downward trend of international oil prices between June 2014-January 2016 (-76\%). Second, low prices of refined products and natural gas in the U.S. market have stimulated a faster growth rate for imports. Third, such imports are not expected to slow down as they are seen as the only way to meet the needs of consumption for automotive fuels, industrial activities, and combined-cycle power plants, which now dominate Mexico's electric industry.

Unable to forecast the path of prices on international oil markets, energy policy has been ineffective to stimulate the production of oil, natural gas and refined products. On the contrary, to counterbalance the energy sector current account deficit and the net energy production deficit during 2014-2018, starting 2017 the government increased between $15 \%$ and $20 \%$ the prices of gasoline and diesel (gas and electricity prices had started growing some months before), leaning on the argument of price liberalization established in the energy reform. That created both surprise and anger in people, as international oil and gas prices, though still volatile, tended to stabilize during 2017 (USEIA, 2017), and the rate of exchange of the Mexican peso to the American dollar was improving.

Beside domestic fuel prices, the only hydrocarbon variable the government holds control on is that of crude oil exports. This is true not only for the recent years but spans along the period 1974-2018, when Mexico became for the second time in history, after the post-revolutionary period, a serious net energy exporter. 
Unfortunately, that has enormous effects on the gasoline and diesel the country produces, the idle capacity of the refineries, the wet gas recuperated from wells, and the country's dependency on fuel imports. Neither present nor previous energy policies have been able to promote the speed of penetration of alternative energy sources or how to incorporate private investment to those sources.

That is why the participation of non-fossil primary energy in the mix of effective primary energy consumption accounts for just 7.7\%, roughly the same proportion registered in 1980 (see figure 1 supra).

Besides, after four years of operation of the energy reform, the strategies of international oil companies have become clear and seem to respond little to national energy and development objectives; for example:

- They are inclined to bid for shallow and deep waters, where hydrocarbon reserves are larger, and tend to dismiss onshore exploration and exploitation.

- They do not feel inclined to profit-sharing and product-sharing contracts, and prefer licensing contracts, which are like the pre-nationalization concessions, as they empower companies and give them the right to sell the hydrocarbons obtained wherever they want, no matter the nationality of the market.

- They put the governments of different hydrocarbon endowed countries in competition for the foreign direct investment geared to the exploration and exploitation of deep-water reserves, as seems to be the case of Mexico and Brazil, in the American continent.

- In the short-run they like too much the gasoline and diesel retail business, and prefer to import their own products rather than investing in refineries, or at least install plants in existing refineries.

- The same is true for the petrochemical industry, where Mexico faces a large and growing commercial deficit, and investment in plants to produce a variety of products is badly needed.

- It has been reported that they could be avoiding the payment of taxes on the international rent of maritime exploration and extraction equipment, as well as on the hiring of specialized personnel.

- They seek to extend as much as possible the starting moment to explore and/or exploit the hydrocarbon areas which tender they won. Though this could in part be explained by the level of international oil prices, the experience shows that it could also be part of their habits to setting aside markets.

- They have the capacity to modify energy policy, as has happened in other countries in similar conditions, such as Argentina and Ecuador, and also happened in Mexico up to 1938's oil nationalization.

\section{Conclusions}

Despite the nine tenders carried out in the hydrocarbon industry and three in the power generation up to November 2018, wining companies barely have put fresh money to the energy sector since 2014. Those resources would supposedly promote industrialization, technological change, jobs generation, price stability, and at least 1.5 additional percentage points to the GDP rate of growth. On the contrary, but in line with the sector's disequilibria, gas and electricity prices started raising in late 2016, and those of gasoline and diesel raised between $15 \%$ and $20 \%$ in January 2017 and kept growing all over 2018, having this a great impact on social inequality and income distribution, as the inflation rate reached in 2017 and 2018 its highest levels since 2002, 5.6\% in the former year and almost $5 \%$ in the later

The impact of Mexico's oil revenues falls during 2015-2018 due to lower international oil prices and additional imports of gasoline and diesel affected different areas of the economy. Given the fact that the decline occurred in a period in which international trade was growing at a slower than historical rate, and Mexico relies too heavily on foreign trade and external capital, the effect on the balance of payments and on the GDP, was considerable. On the one hand, the trade balance of the hydrocarbons and petrochemical industry has fallen in a deep deficit since 2015 , and the loss of oil revenues coupled with the need to support the exchange rate, led to a sustained decline in foreign international reserves held by the central bank during virtually all 2015-2018 period. On this point, it should be borne in mind that historically $88 \%$ of the total foreign exchange that PEMEX received up to 2012 went to the central bank to support those reserves (Heath, 2012: 215). On the other hand, the 2014-2018 oil exports resources which were not obtained by the economy in relation to those of 2013 amount in average to $1.8 \%$ of those years GDP.

Similarly, public finances have suffered the reduction of the oil industry taxes participation on total tax revenues from $35.6 \%$ in 2013 to just over $18.8 \%$ in 2018. Therefore, not only the participation of the Public Sector Borrowing Requirement (PSBR) in GDP has grown, but in just three years in office, the Peña Nieto administration increased 10 percentage points the public sector's debt in terms of GDP. 
Energy policy formulation will continue to be controversial in Mexico. On the one hand, people are convinced that important changes are needed in the energy sector beyond the energy reform open market proposal, and feel that the government may be more interested in the benefits of energy imports and retail commercialization than in the long-term benefits that investment could provide.

In this regard, they have learnt to separate the auction results which the companies take as an invitation to postpone their investment plans from the real need of the country in terms of actual production. People are conscious that given the market conditions and the large maturing process of deep-water oil projects, many years could pass before Mexico reaches gas and oil derivatives self-sufficiency. In addition, they regret the government efforts to diminish the size of the two national energy enterprises, PEMEX and CFE. Quite opposed to that, they believe that reinforcing and being careful about the management of those enterprises could improve the quantity and quality of the services they deliver, being this better than leaning so heavily on foreign companies. Besides, the government and the Judiciary must attend the safety and security of PEMEX installations, where explosions are common and costly, and theft is rampant. Oil platforms, petrochemical plants, refinery plants, refined products storage and pipelines are subject to both types of risk. Smuggling trough pipelines involves a great deal of risk and amounts in average to 1.35 billion dollars per year.

An action still to be evaluated refers to the federal government transfer in an amount equivalent to 10.0 billion dollars to PEMEX through the 2017 federal budget. The money was supposed to reduce PEMEX labor liabilities, which represent at least 10\% of GDP (SHCP, 2016). Besides, the company eliminated 35,000 direct labor posts between 2013 and 2017, and affected 20,000 workers of private companies associated to it. Complementarily, it has been announced that different PEMEX installations, such as those geared to the production of fertilizers and power generation could be sold to private capital, something that was denied during the negotiations of the energy reform. All this precludes a reduction in the size of PEMEX which goes against the way people see the future of the oil industry, where a strong oil national company is considered the only way to counterbalance the power of international oil companies.

At international level, a great deal of changes in the energy sector are about to modify the demand path of fossil fuels. The most important is no doubt the environmental commitment of most nations, with Mexico as one of the most actives of the developing world, to implement the COP 21 (2015 Paris Agreement). What Mexico committed to in such a summit and the following ones (COP 22 and COP 23) was to reduce 25\% its greenhouse gas emissions by 2025 and $50 \%$ by 2040 .

Meanwhile, the governments of the United Kingdom and France have declared that by 2040 all cars circulating on their territories will hold electric technology. On the side of car companies, Volvo announced at early 2017 that starting 2019 it will deliver to the market only electric and hybrid cars, and General Motors is considering doing the same by 2023. Other companies, such as Ford, Toyota, Honda and Volkswagen, which already manufacture and commercialize a considerable number of electric and hybrid cars, seriously expect to increase their production by the early and mid 2020s. All those companies have manufacturing plants in Mexico and are in the process to recompose their production processes. The same transformation is on its way for the second and third more consuming sectors of fossil fuels of the country, which are precisely those which generate more greenhouse gases, industry and electric generation. Due to these circumstances, it is expected that by the mid 2020s the country will be consuming substantially less gasoline, diesel and other fuels than nowadays, despite of the population growth. Then the question is how the government and the oil companies will conciliate the rapid energy substitution process initiated at international level with the faster pace the exploration and exploitation of oil and gas in the Mexican territory is expected by 2025 onwards. This slow pace occurs despite of the oil fields and power generation auctions already carried out, and in general the facilities the energy reform offers to private companies. Due to the above, the short-term goals for the energy policy should be oriented to:

- Increase oil and natural gas production, surely by reinforcing PEMEX activities.

- Increase the use of the installed capacity of PEMEX refineries and petrochemical plants.

- Accelerate the development of energy sources other than fossils, even though CFE's investment.

- Stop the trend of replacing fossil fuels by fossil fuels, i.e. oil by natural gas.

- Reduce the dependence on the imports of gas, gasoline and diesel.

- Make private companies understand the importance of the energy policy linked to the macroeconomic policy and to a real environmental policy. 
- Have a strong hand on the application of the regulatory framework, both in terms of competition and profits accountability, and also regarding the emissions of greenhouse gases.

- Be prepared to regulate regulators, especially CRE, SENER and CNH, whose autonomy could be opposed to the national development goals.

- Give PEMEX the same opportunities as those given to private companies.

- Match the contributions of PEMEX to the treasury with those of the rest of the companies; limit their farm outs and make it invest in the development of the fields and wells assigned to it.

- Do not wait for private companies to invest in refining, petrochemicals, transportation and storage. Take the initiative.

\section{Bibliography}

Centro de Estudios de las Finanzas Públicas (2001), Evolución y Perspectiva del Sector Energetico de Mexico 1970-2000, Mexico: Camara de Diputados.

Comision Federal de Electricidad (CFE) (2015), Estados Financieros, different years, Mexico: CFE.

Comision Nacional de Hidrocarburos (CNH), Rondas Mexico (Rounds Mexico), Accessed August 24, 2017 http://rondasmexico.gob.mx/

Comision Nacional de Inversiones Extranjeras (CNIE) (2018), Informe estadístico sobre el comportamiento de la inversion extranjera directa en Mexico (enero-junio de 2018), Accessed November 1, 2018 https://www.gob.mx/cms/uploads/attachment/file/380643/Informe_Congreso-2018-2T.pdf

Diario Oficial de la Federacion (DOF) (2014), Secondary Laws of the Energy Reform, Mexico: DOF, August 11. (2013), Energy Reform Decree. Mexico: DOF, December 20.

(1992), Ley del Servicio Público de Energia Electrica, Mexico: DOF, December 23.

Gomez-Flores, P. C. and J. L. Gutierrez-Ponce (2016), "Reforma energetica: su impacto sobre PEMEX y las finanzas públicas de Mexico", in Garcia-Alba-Iduñate. P., M. E. Buelna-Serrano, L. Gutierrez-Herrera and F. J. Rodríguez Garza (coordinators), Análisis y Controversias sobre las Actuales Reformas Estructurales, México: UAM/Porrúa.

Gutierrez-R., Roberto (Coordinator) (2017), Presente y Perspectivas de la Reforma Energetica de Mexico, Mexico: Universidad Autonoma Metropolitana unidad Iztapalapa.

(1990), "El sector electrico en Mexico: un análisis de posibilidades y potencialidades hacia el año 2000", Economia: Teoria y Practica, Summer-Fall.

Heath, Jonathan (2012), Lo que Indican los Indicadores, Mexico: INEGI.

Instituto Nacional de Estadistica y Geografia (INEGI) (2017), Indice Nacional de Precios al Consumidor, Accessed November 1, 2018. http://www.beta.inegi.org.mx/proyectos/precios/inpc/

(2017), Producto Interno Bruto, Accessed August 25,http://www.beta.inegi.org.mx/temas/pib/

(2014), La Industria Automotriz en Mexico 2014, Mexico: INEGI, 2014

(2014b), Estadísticas Historicas de México,Mexico: INEGI.

(2016), PIB y Cuentas Nacionales de Mexico, Accessed November 1, 2018, http://www.inegi.org.mx/est/contenidos/proyectos/cn/

International Energy Agency (IEA) (2016), Mexico Energy Outlook. Paris: OECD/IEA.

Luz y Fuerza del Centro (LFC) (2008), Estados Financieros, different years, Mexico: LFC.

Nacional Financiera (NAFIN) (1996), La Economía Mexicana en Cifras, different issues, Mexico: NAFIN.

Organization for Economic Cooperation and Development (OECD) (2017), Consumer Prices, accessed August 25, 2017, http://stats.oecd.org/index.aspx?queryid=22519

Petroleos Mexicanos (PEMEX) (2017), Aaccessed November 1, 2018, http://www.pemex.com/nuestronegocio/Paginas/default.aspx

(2018), Indicadores Petroleros (2018), Accessed November 1, 2018, www.pemex.com

(2014), Anuario Estadistico de PEMEX, Mexico: PEMEX, 2014.

(2007), Anuario Estadistico de PEMEX, Mexico: PEMEX, 2007.

Secretaría de Energia (SENER) (2018), Sistema de Informacion Energetica, accessed November 1, 2018, http://sie.energia.gob.mx/

(2017), Prospectiva del Sector Energetico 2016-2030, accessed January 18, 2017, http://www.gob.mx/sener/documentos/prospectivas-del-sector-energetico 
(2015), Plan Quinquenal de Licitaciones para la Exploracion y Extraccion de Hidrocarburos 2015 2019, Mexico: SENER, June.

Secretaria de Hacienda y Credito Publico (SHCP) (2018), Estadisticas Oportunas de Finanzas Publicas, accessed November 1, 2018, http://presto.hacienda.gob.mx/EstoporLayout/Layout.jsp

(2017), Criterios Generales de Política Económica 2018, Accessed December 18, 2017, http://finanzaspublicas.hacienda.gob.mx/work/models/Finanzas_Publicas/docs/paquete_economico/cgpe/ cgpe_2018.pdf

(2016), Información de finanzas públicas y deuda pública enero-noviembre 2016, accessed November 12 ,

http://finanzaspublicas.hacienda.gob.mx/work/models/Finanzas_Publicas/docs/congreso/fp/2016/FP_201 611.pdf

Secretaria del Trabajo y Prevision Social (STPS) (2018), "Indicadores estratégicos de ocupación y empleo", Accessed November 2, 2018, http://www.stps.gob.mx/gobmx/estadisticas/ENOETRIM15/nal.xls

Senado de la República Diario de Debates (2013), "Proyecto de Reforma Energética", Mexico: Comisiones de Energía, de Puntos Constitucionales, y de Estudios Legislativos, August-December.

US Energy Information Administration (USEIA) (2017), Short Term Energy Outlook, accessed February 12, 2017, https://www.eia.gov/outlooks/steo/archives/jan17.pdf

(2016), International Energy Outlook 2016 with Projections to 2040, Washington: USEIA, May.

Wionczek, Miguel, Oscar Guzman and Roberto Gutierrez-R. (editors) (1988), Energy Policy in Mexico. Problems and Prospects for the Future, Boulder and London: Westview Press. 